\title{
Free Hemoglobin Measurement
}

National Cancer Institute

\section{Source}

National Cancer Institute. Free Hemoglobin Measurement. NCI Thesaurus. Code C127617.

The determination of the amount of free hemoglobin present in a sample. 